\title{
Postauricular Tubed Flap in the Reconstruction of Auricular Margin Defects: Revisited
}

\author{
Aparna Sinha ${ }^{1}$ Shilpi Baranwal ${ }^{2}$ Vaddi Suman Babu² Manoj Kumar Jha ${ }^{2}$ \\ ${ }^{1}$ Department of Plastic Surgery, RIMS, Ranchi, Jharkhand, India \\ 2Department of Burn, Plastic and Maxillofacial Surgery, ABVIMS and \\ Dr. RML Hospital, New Delhi, India

\begin{abstract}
Address for correspondence Vaddi Suman Babu, MS, MCh, Department of Burn, Plastic and Maxillofacial Surgery, ABVIMS and Dr. RML Hospital, New Delhi-110001, India
\end{abstract} \\ (e-mail: augustsuman26@gmail.com).
}

Indian J Plast Surg 2021;54:197-200.

\begin{abstract}
Background Reconstruction of the auricular margin defects is challenging due to the ear's intricate architecture. Tubed flap raised from the postauricular area is a simple and reliable option for reconstructing marginal defects.

Methods Eight patients with various auricular margin defects were reconstructed,

Keywords

- tubed flap

- auricular margin defect

- postauricular flap

- staged reconstruction using a postauricular tubed flap in a staged manner. Parameters like flap survival, reliability, complications, and cosmesis were assessed.

Results Out of eight patients, one patient had marginal necrosis, which was managed with debridement and lengthening of the flap. All the flaps settled well with a good aesthetic outcome.

Conclusion Postauricular tubed flap is a reliable and efficient method for reconstructing auricular margin defects.
\end{abstract}

\section{Introduction}

The ear consists of a thin, pliable, elastic cartilage enveloped in cutaneous tissue. The upper two-third consists of intricate design, with tightly adherent anterior or lateral skin envelope to the underlying perichondrium and no subcutaneous adipose tissue. On the contrary, there is a layer of adipose tissue between the skin and the perichondrium on the posterior or medial aspect of the auricle. The lower one-third is lobule composed of skin and fibrofatty tissue devoid of cartilage. ${ }^{1}$

Auricular margin loss can occur due to various etiologies, including human bite, animal bite, trauma, and burns. Partial loss of the ear helix and lobule leads to deformity, easily noticeable because of its aesthetic importance. So, the defects need to be reconstructed to regain the normal appearance and symmetry, which requires proper planning and execution to obtain the optimum results.

Several techniques are described to reconstruct auricular margin defects, ranging from single-stage to multiple-stage procedures. Out of these, one of the most reliable and straight forward technique is the tubed flap. Gilles introduced it in 1917. Postauricular tubed flap is a well-established technique, which was used extensively before the advent of newer flaps. It has been used in the past and described well in the textbooks. Our study presents the effectiveness of postauricular tubed flap in terms of reliability and aesthetic outcome in reconstructing auricular margin defects.

\section{Materials and Methods}

We included eight patients with auricular margin defects following various etiologies over a period of 2 years from January 2018 to December 2019. Indications of this flap: marginal ear defects including helical rim and lobule. Contraindications included nonmarginal defects, composite ear defects, scar over postauricular region, and low hairline. The reconstruction was performed using three-stage postauricular tubed flap, which was followed-up for 3 to 18 months.

(C) 2021. Association of Plastic Surgeons of India.

This is an open access article published by Thieme under the terms of the Creative Commons Attribution-NonDerivative-NonCommercial-License, permitting copying and reproduction so long as the original work is given appropriate credit. Contents may not be used for commercial purposes, or adapted, remixed, transformed or built upon. (https://creativecommons.org/licenses/by-nc-nd/4.0/).

Thieme Medical and Scientific Publishers Pvt. Ltd. A-12, 2nd Floor, Sector 2, Noida-201301 UP, India 
The parameters like flap survival, reliability, complications, and cosmesis were assessed.

\section{Flap Planning and Markings}

By planning in reverse, a template was made. The flap's width should be twice the width of the defect of the helical rim. The flap doubles up to allow the tube to cover the posterior aspect of the defect. The flap's length and width were taken 2 to $5 \mathrm{~mm}$ more to account for the shrinkage of the flap after raising. The tissue availability is checked by conducting a pinch test in the postauricular area to ensure the donor site's primary closure. Bipedicle flap was marked on the hairless skin over the postauricular area. The anterior margin of the flap was placed close to the auriculocephalic sulcus.

\section{Operative Technique}

It is a three-stage procedure done under local anesthesia with 3 weeks interval between subsequent stages.

In stage 1 , a bipedicle flap was raised in a subcutaneous plane while protecting the subdermal plexus using atraumatic technique. The bipedicle flap was tubed using 6-0 nylon, and the donor defect was closed, primarily using nylon 3-0, by undermining of the surrounding skin. In stage 2 at 3 weeks, one end of the tube was divided, and few millimeters of the tube were laid open. The margins of the defect were freshened; inset was done along the margins and at one end of the defect, incorporating a "V" or " $Z$ " plasty to avoid notching of flap. In stage 3 at 6 weeks, the other limb of the pedicle was also divided. The flap was laid open along the remaining length, and the longitudinal scar was excised. The flap was then completely transposed and inset was done, incorporating "V" plasty using 6-0 nylon. The remaining raw areas at donor sites were closed primarily.

\section{Illustrative Cases}

Case 1

A 25-year-old male had lost a lower-third of the helical rim and part of lobule of the left ear two and half years back following a human bite. He was managed initially with dressings, and after wound healing, a bipedicle postauricular tubed flap reconstruction was done ( - Fig. 1 ).

Case 2

A 22-year-old male had undergone ear reconstruction of left ear lobule type microtia 2 years prior. The helical rim was reconstructed, using a postauricular tubed flap. Later, V-plasty was done for further refinement (-Fig. 2).

\section{Results}

Out of 8 patients, 6 were males and 2 were females, and they were aged between 16 and 54 years ( - Table $\mathbf{1}$ ). Seven patients had uncomplicated intraoperative and postoperative periods. One patient (Case 3) suffered from partial marginal flap necrosis after the first inset, for which debridement of the necrosed part and later flap lengthening was done. All the patients were satisfied with the final aesthetic results.
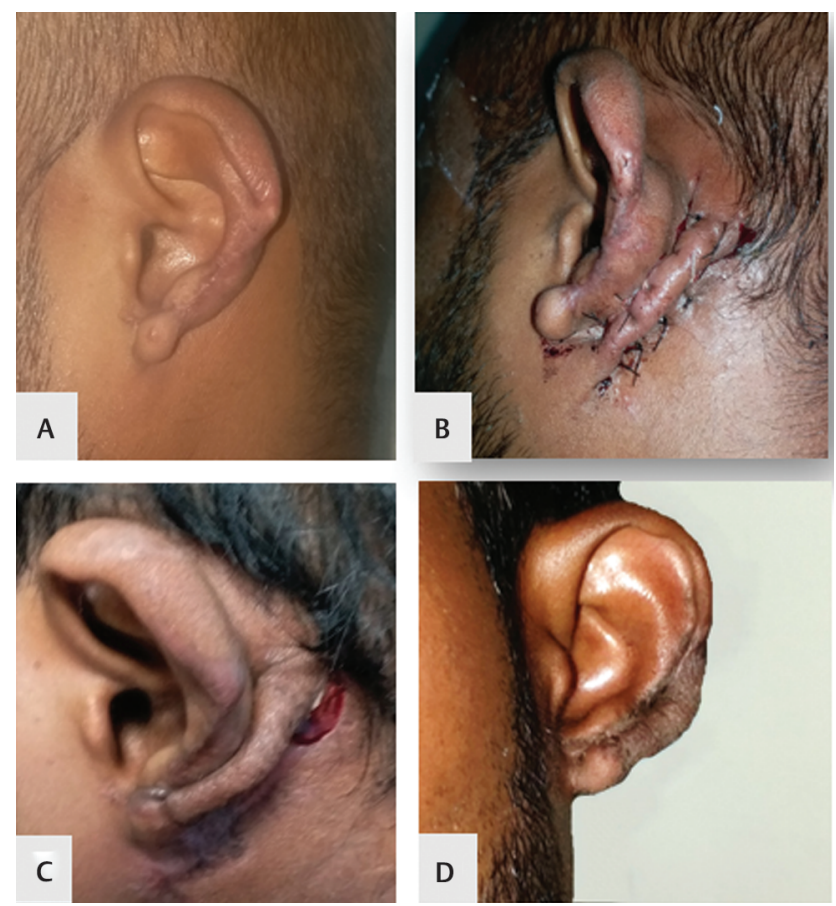

Fig. 1 Case 1. (A) preop picture showing the defect. (B) Tubed flap in situ. (C) Inset of the flap at lower aspect of the defect. (D) Final result at 6 months follow-up.
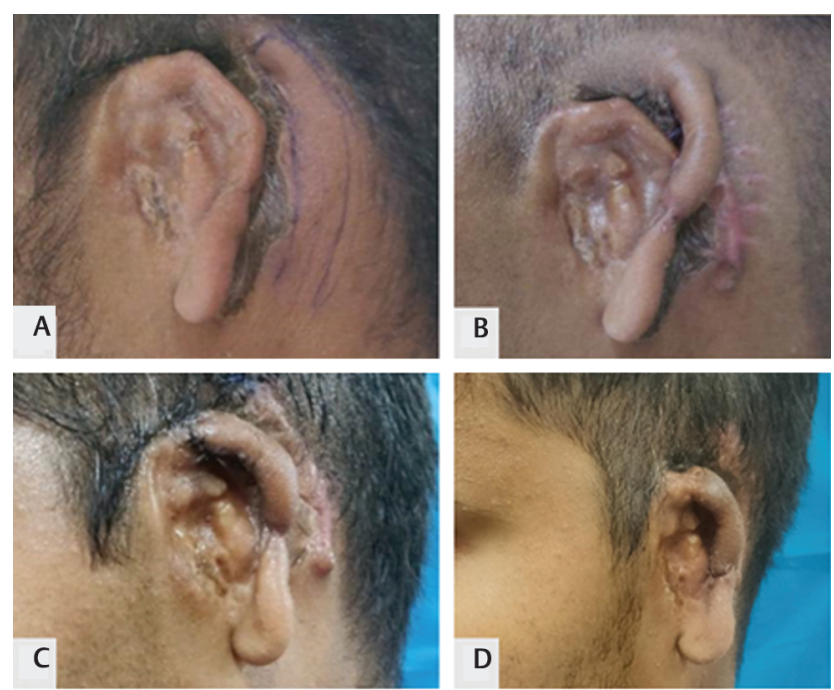

Fig. 2 Case 2 (A) Preop picture showing the defect with markings of the flap. (B) Tube flap inset at lower edge of defect. (C) Flap after complete inset. (D) Final result at 3 months follow-up.

\section{Discussion}

Reconstruction of the auricular margin defects falls into two main categories. One is redistributing the local tissue with resultant compromise on the size of the ear and the other by using the regional tissue as flaps that focus on retaining the normal size. ${ }^{2}$ Based on these criteria, numerous techniques have been described in the literature.

Wedge excision and closure can be done for defects less than $1.5 \mathrm{~cm} .{ }^{1,3}$ The main disadvantage being its limitation to 
Table 1 Demographic profile of the patient and surgical data

\begin{tabular}{|l|l|l|l|l|l|l|}
\hline Case & Age/sex & Etiology & Defect location & $\begin{array}{l}\text { Defect size } \\
\text { (length } \times \\
\text { breath in cm) }\end{array}$ & Complications & Time since injury \\
\hline 1 & 25 years/M & Human bite & $\begin{array}{l}\text { Lower helix and part of } \\
\text { lobule }\end{array}$ & $3.5 \times 1.2$ & Nil & 30 months \\
\hline 2 & 22 years $/ M$ & $\begin{array}{l}\text { Reconstructed ear } \\
\text { for microtia }\end{array}$ & $\begin{array}{l}\text { Middle and lower third } \\
\text { helix }\end{array}$ & $4 \times 1$ & Nil & 24 months \\
\hline 3 & 31 years $/ M$ & Human bite & Middle and lower helix & $3 \times 1$ & $\begin{array}{l}\text { Marginal } \\
\text { necrosis }\end{array}$ & 36 months \\
\hline 4 & 45 years $/ M$ & Knife injury & Middle helix & $2.5 \times 1.2$ & Nil & 6 months \\
\hline 5 & 16 years $/ M$ & Dog bite & Lower helix & $2 \times 1$ & Nil & Nil \\
\hline 6 & 54 years $/ M$ & Dog bite & Middle and lower helix & $4 \times 1.5$ & Nil & 3 months \\
\hline 7 & 43 years $/ F$ & Knife injury & Middle and lower helix & $3.5 \times 1$ & Nil & 2 months \\
\hline 8 & 34 years $/ F$ & Knife injury & $\begin{array}{l}\text { Lower helix and part of } \\
\text { lobule }\end{array}$ & $3 \times 1$ & & \\
\hline
\end{tabular}

defects of less than $15 \%$ of the height, which results in the reduction of the vertical height of the ear. Shonka et al has described the use of the composite graft from the contralateral ear. ${ }^{4}$ Nagel included the wedge resection before composite graft placement to keep the size of composite graft less than $15 \mathrm{~mm}$, in order to improve the take of the graft. ${ }^{5}$

One of the common single-stage local flaps used is AntiaBuch helical advancement. ${ }^{6}$ It is used ideally for defects less than $3 \mathrm{~cm}$, involving the superior and middle part of the helix. This technique's advantages are good cosmesis, preserved anatomical landmarks of the ear, and reliability of the flap. In the case of larger defects, this procedure usually results in a reduction of the size of the ear and requires wedge excision of the normal ear to gain symmetry, which is the main disadvantage. Other techniques of single-stage reconstruction include Millard chondrocutaneous flap and postauricular advancement flaps. ${ }^{7,8}$ But these flaps are not very successful in giving helix the natural border with adjacent scapha.

Although newer methods are available in the pretext of single-stage reconstruction, tubed flap is still relevant in simple settings, as it is reliable and gives good results with minimal morbidity. ${ }^{9}$ The postauricular tubed flap has proven to be an excellent option for auricular margin reconstruction, because of its color, tissue match, rich blood supply, and proximity to the defect. ${ }^{10-12}$ ( - Table 2 ).

Steffanoff described auriculomastoid tubed flap for the reconstruction of helical rim defects, using eight surgical procedures of delays and waltzing over a 5-month period, which showed excellent results. ${ }^{11}$ The order of transfer used was cephalic end first and then caudal end. Later on, Converse and Brent proposed various techniques for reconstruction of helical rim defects along with fine tubed defects. They suggested auriculocephalic sulcus as the preferred site for flap design. ${ }^{13,14}$ Dujon and Bowditch described a three-stage procedure of partial helical defects reconstruction, using a thin post auricular tubed pedicle, at 2 to 4 weeks interval. The flap length to width ratio described was 3 to $6: 1$. The order of transfer used in their study was caudal end first and then cephalic.
Ellabban et al described the postauricular flap for partial ear defects involving helix and lobule. They proposed a two-stage ear reconstruction procedure where immediate reconstruction with a bipedicle flap was done in the first stage, and complete division of flap was done in the second stage. They suggested that immediate transfer was better than tubing the flap, as it reduces the number of stages of reconstruction and the chances of flap shrinkage. Longer defects cannot be resurfaced immediately is the main disadvantage with their method, as the longer flap requires a delay procedure.

Di Mascio et al have described interpolation tubed flap for helical and ear lobe defects. ${ }^{16}$ They reconstructed four ear defects using interpolation flap using three stages. They did not do any preconditioning of the flap, and the vascular compromise was prevented by increasing the duration between two surgeries, which varied from 4 to 6 weeks.

In our series, we used the tubed flap for ear marginal defects involving helix and lobule, similar to a few authors. ${ }^{15,16}$ We were able to close the donor sites primarily in all the cases. The maximum flap dimensions in our series were $40 \mathrm{~mm} \times 15 \mathrm{~mm}$, compared with maximum dimensions of $80 \mathrm{~mm} \times 13 \mathrm{~mm}$ described by Di Mascio et al. In contrast to few authors we did not follow any specific order of transfer. ${ }^{9,12}$ We transferred the flap end that is close to the defect first. We did not do any delay or preconditioning of the flap before inset, and we did not encounter any flap loss.

Although tubed flap reconstruction is a three-stage procedure, it has many advantages. Raising the bipedicle flap is a kind of delay, and it improves the flap vascularity, making it robust. This technique preserves the ear size and shape, unlike other techniques. The tubing at stage 1 allows the flap to attain a rounded shape by stage 2 , which not only gives a raised appearance after transfer but also an aesthetically pleasing and more natural helical contour, which is comparable to the normal ear. This flap provides a good color match with minimal donor site morbidity, the scar is hidden in the postauricular area, and it is done under local anesthesia on an outpatient basis. 
Table 2 Comparison of articles on tubed flap

\begin{tabular}{|c|c|c|c|c|c|c|c|c|}
\hline S.No. & $\begin{array}{l}\text { Author(s), } \\
\text { year }\end{array}$ & $\begin{array}{l}\text { No. of } \\
\text { cases }\end{array}$ & \begin{tabular}{|l|} 
No. of \\
stages
\end{tabular} & \begin{tabular}{|l|} 
Delay or \\
preconditioning
\end{tabular} & \begin{tabular}{|l|} 
Average \\
time interval \\
between two \\
divisions
\end{tabular} & $\begin{array}{l}\text { Order of } \\
\text { transfer }\end{array}$ & $\begin{array}{l}\text { Total/ } \\
\text { average } \\
\text { time } \\
\text { period }\end{array}$ & Discussion \\
\hline 1 & Steffanoff'11 & 1 & 8 & Delay & 4 weeks & $\begin{array}{l}\text { Cephalic end } \\
\text { first }\end{array}$ & 5 months & $\begin{array}{l}\text { He described auriculomastoid tube flap } \\
\text { of size } 68 \mathrm{~mm} \times 18 \mathrm{~mm} \text { in a case with } \\
\text { hypertrichosis. }\end{array}$ \\
\hline 2 & $\begin{array}{l}\text { Dujon and } \\
\text { Bowditch }^{9}\end{array}$ & 3 & 3 & No & 3 weeks & $\begin{array}{l}\text { Caudal end } \\
\text { first }\end{array}$ & 6 weeks & $\begin{array}{l}\text { Width of the flap was kept between } 1.5 \\
\mathrm{~cm}-2 \mathrm{~cm} \text {. Shortest interval between } \\
\text { two stages was } 2 \text { weeks. Used flap from } \\
\text { mastoid region only. }\end{array}$ \\
\hline 3 & $\begin{array}{l}\text { Ellabban } \\
\text { et al. }{ }^{15}\end{array}$ & 3 & 2 & Preconditioning & 0 & Simultaneous & 3 weeks & $\begin{array}{l}\text { At stage } 1 \text {, the flap anterior and } \\
\text { posterior margins were sutured to the } \\
\text { margins of the defect along with carti- } \\
\text { lage graft. At } 2 \text {-weeks, weaning of the } \\
\text { flap done before division }\end{array}$ \\
\hline 4 & $\begin{array}{l}\text { Di Mascio et } \\
\text { al. }{ }^{16}\end{array}$ & 7 & 3 & No & 5 weeks & Not specific & 10 weeks & $\begin{array}{l}\text { The width was kept below } 15 \mathrm{~mm} \text { and } \\
\text { the longest flap raised was } 8 \mathrm{~cm} \text { long. } \\
\text { They obtained better results in trauma } \\
\text { than burn defects. }\end{array}$ \\
\hline
\end{tabular}

\section{Tips and Tricks for Postauricular Tubed Flap}

- Plan the flap with anterior margin close to auriculocephalic sulcus.

- No hurry and wait for 3 weeks to make the flap robust.

- Bipedicle flap can be raised up to 6:1 length width ratio.

- Waltzing without delay up to 4:1 length width ratio.

- Consider delay the flap with more than 4:1 length width ratio.

- Primary inset at defect end that is close to the flap base.

- Avoid tension at inset and lengthen the flap base if required.

- Incorporate "V" plasty at inset to avoid notching.

\section{Conclusion}

Postauricular tubed flap though multi-staged, is a safe and reliable flap for reconstructing middle and lower third auricular margin defects involving helix and lobule with minimal donor site morbidity.

\section{Conflict of Interests}

None.

\section{References}

1 Park SS, Hood RJ. Auricular reconstruction. Otolaryngol Clin North Am 2001;34(4):713-738, v-vi

2 Renard A. Postauricular flap based on a dermal pedicle for ear reconstruction. Plast Reconstr Surg 1981;68(2):159-165

3 Pickrell BB, Hughes CD, Maricevich RS. Partial ear defects. Semin Plast Surg 2017;31(3):134-140
4 Shonka DC Jr, Park SS. Ear defects. Facial Plast Surg Clin North Am 2009;17(3):429-443

5 Nagel F. Reconstruction of a partial auricular loss. Case report. Plast Reconstr Surg 1972;49(3):340-342

6 Antia NH, Buch VI. Chondrocutaneous advancement flap for the marginal defect of the ear. Plast Reconstr Surg 1967;39(5):472-477

7 Millard DR Jr. The chondrocutaneous flap in partial auricular repair. Plast Reconstr Surg 1966;37(6):523-530

8 Lewin ML. Formation of the helix with a postauricular flap. Plast Reconstr Surg (1946) 1950;5(5):432-440

9 Dujon DG, Bowditch M. The thin tube pedicle: a valuable technique in auricular reconstruction after trauma. $\mathrm{Br} \mathrm{J}$ Plast Surg 1995;48(1):35-38

10 Alanis SZ, Retroauricular bipedicle skin flap for partial ear reconstruction. In: Strauch B, Vasconez LO, Hall-Findlay EJ, eds. Grabb's Encyclopedia of Flaps. 2nd ed. Philadelphia: Lippincott-Raven; 1998 308-10

11 Steffanoff DN. Auriculo-mastoid tube pedicle for otoplasty. Plast Reconstr Surg (1946) 1948;3(3):352-360

12 Steffanoff DN, Retroauricular tubed skin flap to the helical rim. In: Strauch B, Vasconez LO, Hall-Findlay EJ, eds. Grabb's Encyclopedia of Flaps. 2nd ed. Philadelphia: Lippincott-Raven; 1998 296-8

13 Tanzer RC, Bellucci RJ, Converse JM, Brent B, Deformities of the auricle. In: Converse JM, ed. Reconstructive Plastic Surgery. Philadelphia: Saunders,; 1977 1671-1773

14 Brent B. The acquired auricular deformity. A systematic approach to its analysis and reconstruction. Plast Reconstr Surg 1977;59(4):475-485

15 Ellabban MG, Maamoun MI, Elsharkawi M. The bi-pedicle post-auricular tube flap for reconstruction of partial ear defects. Br J Plast Surg 2003;56(6):593-598

16 Di Mascio D, Castagnetti F. Tubed flap interpolation in reconstruction of helical and ear lobe defects. Dermatol Surg 2004;30(4 Pt 1) :572-578 